\title{
Sugarcane bagasse as only roughage for crossbred lactating cows in semiarid regions
}

\author{
Wandemberg Rocha Freitas ${ }^{(1)}$, Marcelo de Andrade Ferreira ${ }^{(2)}$, Janaina Lima Silva ${ }^{(3)}$, \\ Antônia Sherlânea Chaves Véras ${ }^{(2)}$, Leonardo José Assis Barros ${ }^{(2)}$, Adryanne Marjorie Souza Vitor Alves ${ }^{(2)}$, \\ Juana Catarina Cariri Chagas ${ }^{(2)}$, Thamires Damascena Quirino Siqueira(2) \\ and Gleidiana Amélia Pontes de Almeida(2)
}

\begin{abstract}
(1)Instituto Federal do Piauí, Campus Paulistana, Rodovia BR 407, Km 5, s/no, Lagoa dos Canudos, CEP 64750-000 Paulistana, PI, Brazil. E-mail: wandembergrocha@hotmail.com (2)Universidade Federal Rural de Pernambuco, Departamento de Zootecnia, Rua Dom Manoel de Medeiros, s/no, Dois Irmãos, CEP 52171-900 Recife, PE, Brazil. E-mail: marcelo.aferreira@ufrpe.br, antonia.veras@ufrpe.br, leonardobarros92@hotmail.com,_dry.marjorie@hotmail.com, juanachagas@gmail.com, thamy_quirino@hotmail.com, ameliazootecnia@gmail.com ${ }^{(3)}$ Universidade Federal do Oeste da Bahia, Centro Multidisciplinar de Barra, Avenida 23 de Agosto, Assunção, CEP 47100-000 Barra, BA, Brazil. E-mail: janaina.lima@ufob.edu.br
\end{abstract}

Abstract - The objective of this work was to evaluate the effects of different levels of sugarcane bagasse, as exclusive roughage, on nutrient intake and digestibility, feeding behavior, microbial protein synthesis, and dairy performance of crossbred cows. Ten lactating Girolando breed cows $(600 \pm 34.3 \mathrm{~kg}$ body weight) were assigned to a replicated $5 \times 5$ Latin square design. The control diet, based on spineless cactus, sugarcane bagasse, and concentrate, was formulated to meet the average production of $20 \mathrm{~kg}$ of milk per day, with $3.5 \%$ fat. The evaluated levels of sugarcane bagasse were: $30,38,46$, and $54 \%$ dry matter bases. The intake and digestibility of dry matter decreased linearly with sugarcane bagasse levels. Rumination time was higher in cows fed 54\% sugarcane bagasse. The inclusion levels had no effect on non-esterified fatty acid contents or on the efficiency of microbial protein synthesis, but beta-hydroxybutyrate concentrations showed a quadratic pattern to the bagasse levels. Higher yields of 3.5\% fat-corrected milk were obtained with cows fed 30\% sugarcane bagasse. Sugarcane bagasse inclusion in the diet of crossbred dairy cows decreases their performance; however, the bagasse can be used as exclusive roughage when associated with $70 \%$ concentrate.

Index terms: alternative roughage, digestibility, feeding behavior, milk yield.

\section{Bagaço de cana-de-açúcar como único volumoso para vacas mestiças lactantes em regiões semiáridas}

Resumo - O objetivo deste trabalho foi avaliar o efeito de diferentes níveis de bagaço de cana-de-açúcar, como volumoso exclusivo, sobre consumo e digestibilidade de nutrientes, comportamento ingestivo, síntese de proteína microbiana e desempenho leiteiro de vacas mestiças. Dez vacas da raça Girolando $(600 \pm 34,3$ $\mathrm{kg}$ de peso corporal) foram distribuídas em delineamento de quadrado latino duplo $5 \times 5$. A dieta controle, baseada em palma forrageira, bagaço de cana-de-açúcar e concentrado, foi formulada para atender a média de produção de $20 \mathrm{~kg}$ de leite por dia, com 3,5\% de gordura. Foram avaliados os seguintes níveis de bagaço de cana-de-açúcar: 30, 38, 46 e 54\% da matéria seca. O consumo e a digestibilidade de matéria seca diminuíram linearmente com os níveis de bagaço. O tempo de ruminação foi maior para vacas alimentadas com $54 \%$ de bagaço. Os níveis de inclusão não tiveram efeito sobre o conteúdo de ácidos graxos não esterificados ou sobre a síntese de proteína microbiana, mas as concentrações de $\beta$-hidroxibutirato apresentaram comportamento quadrático com os níveis de bagaço. Maiores produções de leite corrigido a 3,5\% de gordura foram obtidas com vacas alimentadas com $30 \%$ de bagaço. A inclusão do bagaço de cana-de-açúcar na dieta de vacas mestiças reduz seu desempenho; contudo, o bagaço pode ser utilizado como volumoso exclusivo quando associado a $70 \%$ de concentrado.

Termos para indexação: volumoso alternativo, digestibilidade, comportamento ingestivo, produção de leite.

\section{Introduction}

High variability in rainfall amounts and intensities are characteristic in dryland regions (Carbon..., 2004), like the Brazilian semiarid. According to Koohafkan \&
Stewart (2008), about $40 \%$ of the world total land area is considered drylands, which, nevertheless, provides much of the world grain and livestock. A significant part of cattle are reared in dryland regions by small
Pesq. agropec. bras., Brasília, v.53, n.3, p.386-393, Mar. 2018 DOI: 10.1590/S0100-204X2018000300014 (c) BY This is an open-access article distributed under the Creative Commons Attribution 4.0 International License 
farmers, and their livestock products (milk and meat) provide valuable inputs to their income and nutrition (Mortimore et al., 2009).

The climate challenges of many dryland regions require innovative solutions to maintain food production (Mortimore et al., 2009; Lobell \& Gourdji, 2012). Among the alternatives to livestock production in these areas, the spineless cactus (Opuntia spp.) is considered the most important feed source (Ferreira et al., 2012). Its remarkable tolerance to drought conditions, its high water use efficiency, biomass yield, and contents of soluble carbohydrates justify the species importance for these regions (Ben Salem, 2010). However, the availability of spineless cactus has been limited by the occurrence of an insect known as the carmine cochineal - Dactylopius opuntiae (Hemiptera: Dactylopiidae) -, which compromised its production in a considerable part of the Brazilian semiarid. The introduction of pest resistant spineless cactus varieties is being studied, but it is an option viable only in the medium and long-term, due to limited availability of material for propagation and due to the long crop cycle (two years).

Sugarcane bagasse, however, is highly available in Brazil, which has plenty amount of sugarcane companies, including in states with semiarid regions. Every ton of sugarcane processed results in about 0.3 ton of bagasse (Hofsetz \& Silva, 2012), which can be used as cheap roughage for cattle production (Ahmed $\&$ Babiker, 2015). Thus, the association of sugarcane bagasse and urea can be an attractive option for cattle production in the Brazilian Semiarid, especially in farms not far from sugar and alcohol industry.

Low-quality sugarcane bagasse requires, however, the use of great amounts of concentrate to maintain milk production, but most studies with this roughage were conducted with beef cattle. For dairy cattle, exacerbated amounts of concentrate can bring damage to milk productivity and cause metabolic disorders. Thus, it was hypothesized that the establishment of a proper roughage-to-concentrate ratio, using sugarcane bagasse as the exclusive roughage for lactating cows, could promote improvements in dairy performance and sustainability of livestock production in the Brazilian Semiarid.

The objective of this work was to evaluate the effects of feeding rations with different levels of sugarcane bagasse, as exclusive roughage, on nutrient intake, feeding behavior, dairy performance, and microbial protein synthesis of crossbreed dairy cows.

\section{Materials and Methods}

This study was carried out in the middle region of Agreste and Vale do Ipojuca microregion, in the municipality of Capoeiras, in the state of Pernambuco, Brazil (18 $36^{\prime} 33^{\prime \prime} \mathrm{S}, 36^{\circ} 37^{\prime} 30^{\prime \prime} \mathrm{W}$, and 733-m altitude), in a semiarid climate classified as BSh (Köppen, 1948).

The management and care of animals were performed as per the guidelines and recommendation of the Ethics Committee on Animal Studies of the Universidade Federal Rural de Pernambuco (License no. 033/2014), state of Recife, Brazil. Ten lactating, multiparous, Girolando cows (3/4 and 7/8 Holstein-Gir), with an average initial body weight (BW) of $600 \pm 34.3 \mathrm{~kg}$, were randomly assigned to replicated $5 \times 5$ latin square design, according to the genetic group. The trial lasted 105 days, with five consecutive 21-day periods, divided into a 14-day adaptation and seven days for the sampling period. Animals were housed in individual $16-\mathrm{m}^{2}$ stalls, half-covered, equipped with sand bed and rice straw, automatic waterers, and feeders.

The experimental diets (Table 1) consisted of different levels of sugarcane bagasse: 30, 38, 46, and $54 \%$ of dry matter (DM). A common diet used for crossbred lactating cows in the region, aimed at producing $20 \mathrm{~kg}$ milk per day, based on spineless cactus, sugarcane bagasse, and concentrate (Ferreira et al., 2012), was used as control treatment (Table 2). The diets were formulated to be isonitrogenous, according to the requirements calculated by the NRC (2001) for $600-\mathrm{kg}$ cows producing $20 \mathrm{~kg}$ per day milk, with $3.5 \%$ fat. Sugarcane bagasse was acquired from the local industry.

Animals were fed twice daily, at $7 \mathrm{~h}$ and $16 \mathrm{~h}$, after the morning (4h) and afternoon (15h) milking sessions. The amount of feed supplied was corrected daily, which allowed ad libitum intake, with $10 \%$ refusal in the fresh matter, and water was available ad libitum. Samples of feeds and refusals were collected during the last seven days of each experimental period and stored at $-20^{\circ} \mathrm{C}$, in airtight plastic bags. The BW of each cow was measured at the start and at the end of each period, after the morning milking.

From the $17^{\text {th }}$ to the $21^{\text {st }}$ day of each period, from $6 \mathrm{~h}$ to $14 \mathrm{~h}$, the fecal dry matter output was estimated. Spot fecal samples, collected directly from the animals' rectums, were used to assess the total apparent digestibility of nutrients. The indigestible neutral detergent fiber (iNDF) content was used as an internal 
marker analyzed in the fecal, feed, and refusal samples, obtained by using in situ procedures, with $288 \mathrm{~h}$ of rumen incubation in cattle (Valente et al., 2015).

Feeding behavior was evaluated by the scan sampling method and recording five-minute period intervals, for 24 hours, adapted to three consecutive days (72 hours), according to Martin \& Bateson (2007). Cow observation started immediately after the morning feeding, and the assay occurred on the fourth day of each sampling period. The activity of each cow was recorded as rumination, feeding, and idling. The feeding and rumination efficiency $\left(\mathrm{kg} \mathrm{h}^{-1}\right)$ were calculated by dividing DM intake by total feeding or rumination times, respectively.

Blood samples were collected on the $15^{\text {th }}$ day, 4 hours after feeding, by coccygeal venipuncture, in two tubes: one with anticoagulant (heparin) and another containing sodium fluoride. After collection, the blood samples were immediately centrifuged at $3,500 \mathrm{~g}$, for $15 \mathrm{~min}$, and then one aliquot was taken from each tube for urea, non esterified fatty acids (Nefa), and betahydroxybutyrate (BHBA) determinations. For the determination of urea, Labtest commercial kit was

Table 1. Nutrient composition of the experimental diets.

\begin{tabular}{lccccc}
\hline Item & Control & \multicolumn{5}{c}{ Sugarcane bagasse levels (\%) } \\
\cline { 3 - 6 } & & 30 & 38 & 46 & 54 \\
\hline Ingredients $\left(\mathrm{g} \mathrm{kg}^{-1}\right)$ & & & & & \\
Sugarcane bagasse & 300 & 300 & 380 & 460 & 540 \\
Spineless cactus & 400 & 0 & 0 & 0 & 0 \\
Ground corn & 75.0 & 493 & 411 & 328 & 246 \\
Soybean meal & 185 & 173 & 173 & 173 & 173 \\
Urea + ammonium sulfate ${ }^{(1)}$ & 10.0 & 4.00 & 6.50 & 9.00 & 11.5 \\
Salt & 5.0 & 5.00 & 5.00 & 5.00 & 5.00 \\
Sodium bicarbonate & 10.0 & 10.0 & 10.0 & 10.0 & 10.0 \\
Mineral mix ${ }^{(2)}$ & 15.0 & 15.0 & 15.0 & 15.0 & 15.0 \\
\hline Diet composition (g kg $\left.{ }^{-1}\right)$ & & & & & \\
Dry matter (DM) & 394 & 719 & 685 & 654 & 626 \\
Organic matter (OM) & 899 & 932 & 927 & 922 & 917 \\
Crude protein (CP) & 142 & 145 & 146 & 145 & 149 \\
Ether extract (EE) & 15.6 & 32.5 & 28.9 & 25.2 & 21.5 \\
NDFap (3) & 373 & 281 & 345 & 405 & 463 \\
Total carbohydrates & 783 & 793 & 794 & 794 & 795 \\
Non-fiber carbohydrates & 354 & 439 & 382 & 323 & 266 \\
Total digestible nutrients & 693 & 698 & 663 & 662 & 652 \\
\hline
\end{tabular}

(1)Proportion between urea and ammonium sulfate: 9:1. ${ }^{(2)}$ Dicalcium phosphate, limestone, salt, sulfur, zinc sulfate, copper sulfate, manganese sulfate, potassium iodate, and sodium selenite. ${ }^{(3)} \mathrm{NDFap}$, neutral detergent fiber corrected for ash and nitrogenous compounds. used, and for Nefa and BHBA, Randox commercial kits were used.

Spot urine samples were obtained on the $15^{\text {th }}$ day of each experimental period, 4 hours after the first feed supply of the day (Chizzotti et al., 2008). Analyses of allantoin were performed by using a colorimetric method (Chen \& Gomes, 1992), and total nitrogen, urea, uric acid, and creatinine were obtained using an automatic biochemical analyzer, LabMax 240 (Labtest Diagnostica S.A., Lagoa Santa, MG, Brazil).

Samples of feeds, refusals, and feces were analyzed for dry matter (DM; method 934.01), organic matter (OM; method 930.05), crude protein (CP; method 968.06), and ether extract (EE; method 920.39) according to Horwitz (2000). Dry matter was analyzed by the gravimetric difference between dry and wet sample weights; CP using the macro-Kjeldahl procedure, multiplied by a factor of 6.25 ; and $\mathrm{EE}$, by Soxhlet extraction with petroleum ether. Analysis of neutral detergent fiber (NDF) followed Mertens (2002), using a heat-stable alpha-amylase, without using sodium sulfite, and corrected for residual ash. The NDF was also corrected for the nitrogenous compounds content, using the method described by Licitra et al. (1996). These chemical analyses were performed in samples processed to pass through a 1-mm screen sieve. The quantification of non-fibrous carbohydrates (NFC) content was performed according to Hall (2001), and the total digestible nutrients (TDN) were determined according to Weiss (1999).

The nitrogenous compound balance (N-retained) was obtained by calculating the difference between total

Table 2. Chemical composition of the experimental diets.

\begin{tabular}{|c|c|c|c|c|}
\hline \multirow[t]{2}{*}{ Item } & \multicolumn{4}{|c|}{ Ingredients $\left(\mathrm{g} \mathrm{kg}^{-1}\right)$} \\
\hline & $\begin{array}{c}\text { Sugarcane } \\
\text { bagasse }\end{array}$ & $\begin{array}{c}\text { Spineless } \\
\text { cactus } \\
\end{array}$ & $\begin{array}{c}\text { Ground } \\
\text { corn }\end{array}$ & $\begin{array}{c}\text { Soybean } \\
\text { meal }\end{array}$ \\
\hline Dry matter (DM) & 502 & 252 & 899 & 901 \\
\hline Organic matter (OM) & 951 & 920 & 985 & 932 \\
\hline Crude protein $(\mathrm{CP})$ & 15.2 & 41.0 & 89.0 & 471 \\
\hline Ether extract (EE) & 9.50 & 13.9 & 54.1 & 18.7 \\
\hline NDFap $^{(1)}$ & 831 & 279 & 76.8 & 92.8 \\
\hline $\mathrm{iNDF}^{(2)}$ & 382 & 50.7 & 25.8 & 18.9 \\
\hline Lignin & 124.4 & 49.4 & 13.0 & 14.9 \\
\hline Total carbohydrates & 926 & 866 & 842 & 445 \\
\hline Non-fiber carbohydrates & 95.3 & 589 & 765 & 352 \\
\hline
\end{tabular}

(1)NDFap, neutral detergent fiber corrected for ash and nitrogenous compounds. ${ }^{(2)}$ iNDF, indigestible neutral detergent fiber. 
nitrogen intake (NI) and total nitrogen excreted in the feces (N-fecal), urine (N-urinary), and milk (N-milk). The efficiency of dietary $\mathrm{N}$ compound utilization was assayed by using the following indicators: N-urea in plasma, urinary excretion of $\mathrm{N}$-urea, and $\mathrm{N}$ balance.

Milk production was measured daily, during the collection period. Milk samples were collected on the $19^{\text {th }}$ and $20^{\text {th }}$ days of each period, for the analyses of protein, fat, lactose, urea, and total solid content, according to ISO 9622/IDF 141C (ISO, 2013). Milk yield values were corrected for $3.5 \%$ fat, according to Sklan et al. (1992).

The bioeconomics of the diets were evaluated considering the feeding cost per $\mathrm{kg}$ of milk produced and gross margin, for prices current in the first half of 2017.

The data were submitted to the analysis of variance, and regression analyses were performed with Proc Mixed procedure of SAS, version 9.4 (SAS Institute, Cary, NC, USA), at $5 \%$ probability, according to the model: $\mathrm{Y}_{\mathrm{ijkl}}=\mu+\tau_{\mathrm{i}}+\mathrm{Q}_{\mathrm{j}}+\mathrm{P}_{\mathrm{k}}+(\mathrm{A} / \mathrm{Q})_{\mathrm{lj}}+\tau \times \mathrm{Q}_{\mathrm{ij}}+\varepsilon_{\mathrm{ijk}}$ in which: $Y_{\mathrm{ijkl}}$ is the observation $\mathrm{ijkl} ; \mu$, the general mean; $\tau_{i}$, the treatment fixed effect $i ; Q_{j}$, the square fixed effect $\mathrm{j} ; \mathrm{P}_{\mathrm{k}}$, the period fixed effect $\mathrm{k}$; $(\mathrm{A} / \mathrm{Q})_{\mathrm{l} j}$, the animal 1 into square $\mathrm{j}$ random effect; $\tau \times \mathrm{Q}_{\mathrm{ij}}$, the interaction effect of treatment $i$ and square $j$; and $\varepsilon_{\mathrm{ijk} k}$, the random error with mean 0 and variance $\sigma^{2}$.

Dunnett test was used to compare each treatment group mean (sugarcane bagasse levels), with the average of control diet. Comparisons between sugarcane bagasse levels in the diets were conducted by the decomposition of sum of squares in orthogonal linear contrasts, and quadratic effects, at $5 \%$ probability, with subsequent adjustments of the regression equations.

\section{Results and Discussion}

The intakes of DM, OM, CP, NFC, and TDN decreased linearly with the sugarcane bagasse levels (Table 3). There was a quadratic effect for NDFap intake, with a maximum value of $6.54 \mathrm{~kg}$ per day, estimated at $48.2 \%$ sugarcane bagasse. DM digestibility decreased linearly, while the digestibility of $\mathrm{CP}$ and NDF increased linearly with the increased levels.

Excess of low degradability fiber from sugarcane bagasse decreased dietary DM digestibility, which was reflected in the reduction of intake and increase of rumination activities. The fraction of slowly digestible, or indigestible fiber, taking up space in the animal's gastrointestinal tract, caused rumen-filling as a result of distension in the rumen (Mertens, 1997). Consequently, the cows ingested the diets until they reached their maximum capacity for NDF intake. According to Ahmed et al. (2013), the use of sugarcane bagasse for animal feeding is limited by their lowdigestibility, and could be related to their high content of fiber with more than $60 \%$ cellulose, hemicellulose, and lignin.

A linear increase for feeding time and rumination was observed with bagasse increasing levels, and a linear decrease of idle time (Table 4). The animals spent more time ingesting feed; nevertheless, they presented lower DM intake (Table 3), suggesting that greater NDF in diets with more inclusion of bagasse increased animal selectivity (Parente et al., 2016) and, as a consequence, feeding efficiency was lower. The highest values observed for rumination time can be justified by the highest NDF intake observed for diets with greater bagasse inclusion. The rumination efficiency was better for diets with more concentrate inclusion and less bagasse (Table 4), since, in this case, the DM intake was high and the rumination time was lower.

The effects of sugarcane bagasse levels on Nefa and BHBA concentration showed a quadratic pattern, with the highest value estimated as $0.56 \mathrm{mmol} \mathrm{L}^{-1}$, with $43.1 \%$ of bagasse (Table 5). In spite of the quadratic response of BHBA, this metabolite and Nefa ranged from 0.11 to 0.14 , and from 0.51 to $0.58 \mathrm{mmol} \mathrm{L}^{-1}$, respectively, indicating a normal metabolism condition, since they are great indicators of body mobilization and subclinical ketosis, respectively (Adewuyi et al., 2005; González et al., 2011). This can be better understood by observing the animal's weight gain during the trial.

Although a quadratic effect of the inclusion levels was observed on $\mathrm{N}$ balance, biologically, the linear effect was the most adequate for explaining such a response due to the behavior of $\mathrm{N}$ intake and $\mathrm{N}$ excretion in feces, urine, and milk (Table 5). $\mathrm{N}$ use efficiency was harmed with the bagasse inclusion, since it decreased for milk, and the concentration of urea in plasma and milk increased. A better efficiency for milk can be associated with quantitative increase in the microbial protein for diets with less bagasse inclusion (1,604 g per day), as most amino acids absorbed in the small intestine come from microbial protein and present a high-quality amino acid profile, 
even comparable to the milk profile (Titgemeyer, 2003). A lower urea concentration in plasma and milk is related to the synchronism (energy: $\mathrm{N}$ ) in rumen (Siqueira et al., 2017) promoted by high levels of nonfibrous carbohydrates in the diets due to the inclusion of high concentrate levels (Inácio et al., 2017).

The urea concentration in urine showed a quadratic response, with minimal value estimated at 70.9 (mg dL ${ }^{-1}$ ), with $41.97 \%$ bagasse inclusion (Table 5). Microbial protein decreased linearly with bagasse inclusion, while the efficiency of microbial synthesis did not differ. As the efficiency of synthesis did not change, the decrease in microbial syntheses was related to the low TDN intake, observed for diets with high bagasse inclusion. The efficiency of microbial protein synthesis (127 $\mathrm{g}$ crude protein per $\mathrm{kg}$ of TDN) is in accordance with the recommendation for crossbred cattle raised in tropical areas - $120 \mathrm{~g} \mathrm{~kg}^{-1}$ (Pina et al., 2010).
Milk yield, corrected for 3.5\% fat, decreased linearly with bagasse inclusion, accordingly to the linear decrease observed for NDT and CP intakes (Table 3).

The milk fat was not altered by the bagasse inclusion levels, with a mean of $3.68 \mathrm{~g}$ per $100 \mathrm{~g}$ (Table 6), which can be justified by the adequacy of effective fiber content in experimental diets. According to NRC (2001), diets with $25 \%$ NDF in total and $44 \%$ non-fiber carbohydrates should present, at least, 76\% NDF from the roughage (longer fiber) in order to guarantee the maintenance of milk fat at normal levels. Considering the bagasse inclusion of $30 \%$, the total NDF was 281 g per $100 \mathrm{~g}$ and NFC was $44 \mathrm{~g}$ per $100 \mathrm{~g}$; thus, the total NDF was $89 \%$, provided by sugarcane bagasse (longer fiber), which meets the NRC recommendation.

Milk protein and lactose decreased linearly with the bagasse inclusion (Table 6). Milk components can be altered with diet composition, since the substrates for

Table 3. Intake and digestibility of nutrients in cows according to different sugarcane bagasse levels ${ }^{(1)}$.

\begin{tabular}{|c|c|c|c|c|c|c|c|c|c|c|}
\hline \multirow[t]{2}{*}{ Item } & \multirow[t]{2}{*}{ Control } & \multicolumn{4}{|c|}{ Sugarcane bagasse levels (\%) } & \multirow[t]{2}{*}{$\mathrm{SEM}^{(2)}$} & \multicolumn{2}{|c|}{ Contrasts } & \multirow[t]{2}{*}{ Regression } & \multirow[t]{2}{*}{$\mathrm{R}^{2}$} \\
\hline & & 30 & 38 & 46 & 54 & & Linear & Quadratic & & \\
\hline & \multicolumn{10}{|c|}{ Intake (kg per day) } \\
\hline Dry matter & 18.3 & 18.3 & 17.8 & $16.1 \mathrm{a}$ & $13.9 \mathrm{a}$ & 0.506 & $* *$ & ns & $\hat{\mathrm{Y}}=24.3162-0.1855 \mathrm{x}$ & 93.68 \\
\hline Organic matter & 16.5 & 17.0 & 16.5 & $14.8 \mathrm{a}$ & $12.7 \mathrm{a}$ & 0.467 & $* *$ & ns & $\hat{\mathrm{Y}}=22.9185-0.1822 \mathrm{x}$ & 94.52 \\
\hline Crude protein & 2.60 & 2.66 & 2.60 & $2.38 \mathrm{a}$ & $2.07 \mathrm{a}$ & 0.069 & $* *$ & ns & $\hat{\mathrm{Y}}=3.4673-0.0248 \mathrm{x}$ & 92.44 \\
\hline $\mathrm{NDFap}^{(3)}$ & 6.83 & $5.15 \mathrm{a}$ & $6.13 \mathrm{a}$ & 6.53 & 6.43 & 0.215 & $* *$ & $* *$ & $\hat{Y}=-3.2204+0.4049 x-0.0042 x^{2}$ & 99.97 \\
\hline $\mathrm{NFC}^{(4)}$ & 7.21 & $8.80 \mathrm{a}$ & 7.51 & $5.93 \mathrm{a}$ & $4.35 \mathrm{a}$ & 0.202 & $* *$ & ns & $\hat{\mathrm{Y}}=14.4734-0.1863 \mathrm{X}$ & 99.77 \\
\hline \multirow[t]{2}{*}{$\mathrm{TDN}^{(5)}$} & 12.7 & 12.8 & $11.8 \mathrm{a}$ & $10.7 \mathrm{a}$ & $9.06 \mathrm{a}$ & 0.571 & $* *$ & ns & $\hat{\mathrm{Y}}=17.1687-0.1461 \mathrm{x}$ & 97.51 \\
\hline & \multicolumn{10}{|c|}{ Digestibility $\left(\mathrm{g} \mathrm{kg}^{-1}\right)$} \\
\hline Dry matter & 736 & $705 \mathrm{a}$ & $685 \mathrm{a}$ & $679 a$ & $671 \mathrm{a}$ & 12.9 & $* *$ & ns & $\hat{Y}=741.575-1.344 x$ & 91.59 \\
\hline Organic matter & 760 & $724 a$ & $705 \mathrm{a}$ & $709 a$ & $701 \mathrm{a}$ & 12.7 & ns & ns & - & - \\
\hline Crude protein & 814 & $749 a$ & $758 \mathrm{a}$ & $777 \mathrm{a}$ & 782 & 13.8 & $* *$ & ns & $\hat{\mathrm{Y}}=706.013+1.441 \mathrm{x}$ & 95.96 \\
\hline NDFap & 535 & $397 \mathrm{a}$ & $431 \mathrm{a}$ & $460 \mathrm{a}$ & 492 & 22.7 & $* *$ & ns & $\hat{\mathrm{Y}}=279.202+3.947 \mathrm{x}$ & 99.94 \\
\hline
\end{tabular}

${ }^{(1)}$ Means followed by equal letters do not differ from the control treatment, according to the Dunnett test at $5 \%$ probability. ${ }^{(2)}$ SEM, standard error of the mean. ${ }^{(3)}$ NDFap, neutral detergent fiber corrected for ash and nitrogenous compounds. ${ }^{(4)} \mathrm{NFC}$, non-fiber carbohydrates. ${ }^{(5)} \mathrm{TDN}$, total digestible nutrients. **Significant at $1 \%$ probability. ${ }^{\mathrm{n}}$ Nonsignificant.

Table 4. Feeding behavior of cows according to different sugarcane bagasse levels ${ }^{(1)}$.

\begin{tabular}{|c|c|c|c|c|c|c|c|c|c|c|}
\hline \multirow[t]{2}{*}{ Item } & \multirow[t]{2}{*}{ Control } & \multicolumn{4}{|c|}{ Sugarcane bagasse levels (\%) } & \multirow[t]{2}{*}{$\mathrm{SEM}^{(2)}$} & \multicolumn{2}{|c|}{ Contrasts } & \multirow[t]{2}{*}{ Regression } & \multirow[t]{2}{*}{$\mathrm{R}^{2}$} \\
\hline & & 30 & 38 & 46 & 54 & & $\mathrm{~L}^{(3)}$ & $\mathrm{Q}^{(4)}$ & & \\
\hline Eating (min per day) & 329 & $283 a$ & 324 & 320 & 325 & 9.45 & $*$ & $*$ & $\hat{Y}=12.13+13.33 x-0.14 x^{2}$ & 87.99 \\
\hline Ruminating (min per day) & 407 & 393 & 448 & 464 & $476 \mathrm{a}$ & 26.5 & * & $*$ & $\hat{Y}=1,404.59-30.75 x+0.30 x^{2}$ & 95.81 \\
\hline Idle (min per day) & 704 & 764 & 668 & 656 & 639 & 29.1 & $*$ & ns & $\hat{\mathrm{Y}}=306.1250-3.3125 \mathrm{x}$ & 87.03 \\
\hline Feed efficiency $\left(\mathrm{kg} \mathrm{min}^{-1}\right)$ & 3,371 & $3,920 \mathrm{a}$ & 3,304 & $3,028 \mathrm{a}$ & $2,575 \mathrm{a}$ & 78.6 & $* *$ & ns & $\hat{Y}=5,469.6316-53.8733 x$ & 97.90 \\
\hline Rumination efficiency $\left(\mathrm{kg} \mathrm{min}^{-1}\right)$ & 2,746 & 2,960 & 2,467 & $2,180 \mathrm{a}$ & $1,776 \mathrm{a}$ & 93.3 & $*$ & ns & $\hat{Y}=4,362.1638-48.0074 x$ & 99.04 \\
\hline
\end{tabular}

${ }^{(1)}$ Means followed by equal letters do not differ from the control treatment, according to the Dunnett test at $5 \%$ probability. ${ }^{(2)}$ SEM, standard error of the

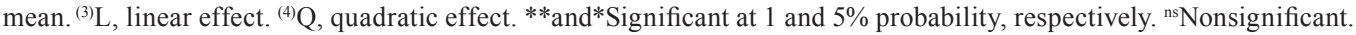


mammary synthesis of milk components are provided by the fermentation in the rumen and by the digestion of the small intestine carbohydrates, affecting milk yield directly through the supply of glucose to the mammary gland and milk protein through the growth limitation of ruminal bacteria (Chalupa \& Sniffen, 2000).

The diet bio-economics system evaluation (Table 7) showed that the feeding cost per $\mathrm{kg}$ of milk produced was lower for high-level bagasse diet; however, considering the gross margin ( $\mathrm{R} \$$ per cow per day), the greater value was obtained with lower bagasse inclusion. Therefore, the high inclusion of expensive concentrated feedstuff was offset by the high milk production.

The control diet promoted the expected milk yield, as verified in other works with spineless cactus (Ferreira et al., 2010), and this result from an experiment with controlled diets corroborates the importance of the species for smallholder dairy system in semiarid regions.

Table 5. Blood metabolites, nitrogen balance, $\mathrm{N}$ use efficiency, urea nitrogen, and microbial protein synthesis of cows according to different sugarcane bagasse levels ${ }^{(1)}$.

\begin{tabular}{|c|c|c|c|c|c|c|c|c|c|c|}
\hline \multirow[t]{2}{*}{ Item } & \multirow[t]{2}{*}{ Control } & \multicolumn{4}{|c|}{ Sugarcane bagasse levels (\%) } & \multirow[t]{2}{*}{$\mathrm{SEM}^{(2)}$} & \multicolumn{2}{|c|}{ Contrasts } & \multirow[t]{2}{*}{ Regression } & \multirow[t]{2}{*}{$\mathrm{R}^{2}$} \\
\hline & & 30 & 38 & 46 & 54 & & $L^{(3)}$ & $\mathrm{Q}^{(4)}$ & & \\
\hline & \multicolumn{10}{|c|}{ Blood metabolite $\left(\mathrm{mmol} \mathrm{L}^{-1}\right)$} \\
\hline $\mathrm{Nefa}^{(5)}$ & 0.09 & 0.11 & 0.12 & 0.14 & 0.12 & 0.02 & ns & $\mathrm{ns}$ & - & - \\
\hline \multirow[t]{2}{*}{$\mathrm{BHBA}^{(6)}$} & 0.64 & $0.51 \mathrm{a}$ & $0.55 \mathrm{a}$ & $0.58 \mathrm{a}$ & $0.52 \mathrm{a}$ & 0.04 & ns & $*$ & $\hat{Y}=-0.1223+0.320 x-0.0003 x^{2}$ & 91.74 \\
\hline & \multicolumn{10}{|c|}{ Nitrogen balance $\left(\mathrm{g}\right.$ day $\left.^{-1}\right)$} \\
\hline Total $\mathrm{N}$ intake & 416 & 425 & 416 & $380 \mathrm{a}$ & $332 \mathrm{a}$ & 11.2 & $* *$ & ns & $\hat{\mathrm{Y}}=554.9144-3.9731 \mathrm{x}$ & 92.58 \\
\hline N Feces & 84.6 & $117 \mathrm{a}$ & $109 a$ & 90.0 & 76.9 & 4.06 & $* *$ & ns & $\hat{Y}=170.6985-1.7265 x$ & 97.67 \\
\hline N Urine & 0.34 & 0.44 & 0.28 & 0.26 & 0.29 & 0.06 & ns & ns & - & - \\
\hline N Milk & 97.9 & $114 \mathrm{a}$ & 102 & $89.3 \mathrm{a}$ & $79.7 \mathrm{a}$ & 2.91 & $* *$ & ns & $\hat{\mathrm{Y}}=156.5534-1.4364 \mathrm{x}$ & 99.69 \\
\hline \multirow[t]{2}{*}{ Balance } & 232 & $194 \mathrm{a}$ & $204 \mathrm{a}$ & $201 \mathrm{a}$ & $174 \mathrm{a}$ & 11.5 & $*$ & $* *$ & $\hat{Y}=-10.9849+11.0717 x-0.141383 x^{2}$ & 99.21 \\
\hline & \multicolumn{10}{|c|}{$\mathrm{N}$ use efficiency (NUE) } \\
\hline \multirow[t]{2}{*}{ Milk } & 0.236 & $0.260 \mathrm{a}$ & 0.247 & 0.246 & 0.240 & 0.005 & $* *$ & $\mathrm{~ns}$ & $\hat{Y}=0.2793-0.0007 x$ & 85.55 \\
\hline & \multicolumn{10}{|c|}{ Urea nitrogen $\left(\mathrm{mg} \mathrm{dL}^{-1}\right)$} \\
\hline Plasma & 23.1 & 28.7 & 29.9 & 35.7 & 35.7 & 1.32 & $* *$ & $\mathrm{~ns}$ & $\hat{\mathrm{Y}}=39.5640-0.7152 \mathrm{x}$ & 85.99 \\
\hline Urine & 74.9 & 87.3 & 71.3 & 74.2 & 86.6 & 7.65 & ns & $*$ & $\hat{Y}=1,665.7391-58.2670 x-0.6943 x^{2}$ & 97.87 \\
\hline \multirow[t]{2}{*}{ Milk } & 17.1 & 19.4 & $22.5 \mathrm{a}$ & $26.4 \mathrm{a}$ & $27.1 \mathrm{a}$ & 1.21 & $* *$ & ns & $\hat{\mathrm{Y}}=9.5945+0.3395 \mathrm{x}$ & 94.10 \\
\hline & \multicolumn{10}{|c|}{ Microbial protein synthesis } \\
\hline $\mathrm{MCP}^{(7)}$ (g per day) & 1,594 & 1,604 & 1,487 & $1,275 \mathrm{a}$ & $1,248 \mathrm{a}$ & 91.8 & $* *$ & ns & $\hat{\mathrm{Y}}=2,076.1955-16.0168 \mathrm{x}$ & 93.29 \\
\hline $\operatorname{EMPS}^{(8)}\left(\mathrm{g} \mathrm{kg}^{-1}\right)$ & 125.5 & 125.3 & 126.0 & $119 \mathrm{a}$ & 137.7 & 5.37 & ns & ns & - & - \\
\hline Daily gain (kg per cow) & 0.31 & 0.34 & 0.30 & 0.31 & 0.31 & - & - & - & - & - \\
\hline
\end{tabular}

Table 6. Milk yield and composition of cows according to different sugarcane bagasse levels ${ }^{(1)}$.

\begin{tabular}{|c|c|c|c|c|c|c|c|c|c|c|}
\hline \multirow[t]{2}{*}{ Item } & \multirow[t]{2}{*}{ Control } & \multicolumn{4}{|c|}{ Sugarcane bagasse levels (\%) } & \multirow[t]{2}{*}{$\mathrm{SEM}^{(2)}$} & \multicolumn{2}{|c|}{ Contrasts (p-value) } & \multirow[t]{2}{*}{ Regression } & \multirow[t]{2}{*}{$\mathrm{R}^{2}$} \\
\hline & & 30 & 38 & 46 & 54 & & Linear & Quadratic & & \\
\hline & \multicolumn{10}{|c|}{ Milk yield (kg per day) } \\
\hline Milk & 19.7 & $22.4 \mathrm{a}$ & 20.6 & $18.5 \mathrm{a}$ & $16.4 \mathrm{a}$ & 0.74 & $* *$ & ns & $\hat{Y}=29.9765-0.2507 x$ & 99.85 \\
\hline $3.5 \% \mathrm{FCM}^{(3)}$ & 19.9 & $22.7 \mathrm{a}$ & 21.4 & 19.4 & $16.5 \mathrm{a}$ & 1.03 & $* *$ & ns & $\hat{Y}=30.8634-0.2589 x$ & 97.17 \\
\hline & \multicolumn{10}{|c|}{ Milk composition (g per $100 \mathrm{~g}$ ) } \\
\hline Fat & 3.56 & 3.61 & 3.77 & 3.78 & 3.54 & 0.19 & ns & ns & - & \\
\hline Protein & 3.19 & 3.25 & 3.19 & 3.11 & 3.11 & 0.07 & $*$ & ns & $\hat{\mathrm{Y}}=3.43-0.0063 \mathrm{x}$ & 87.05 \\
\hline Lactose & 4.71 & 4.82 & 4.77 & 4.71 & 4.66 & 0.04 & $* *$ & ns & $\hat{\mathrm{Y}}=5.0176-0.0065 \mathrm{x}$ & 99.71 \\
\hline Total solids & 12.3 & 12.3 & 12.5 & 12.2 & 12.2 & 0.15 & $\mathrm{~ns}$ & ns & - & - \\
\hline
\end{tabular}

${ }^{(1)}$ Means followed by equal letters do not differ from the control treatment, according to the Dunnett test at $5 \%$ probability. ${ }^{(2)}$ SEM, standard error of

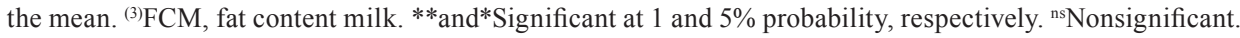


Table 7. Bioeconomic system evaluation.

\begin{tabular}{|c|c|c|c|c|c|}
\hline \multirow[t]{2}{*}{ Item $^{(1)}$} & \multirow[t]{2}{*}{ Control } & \multicolumn{4}{|c|}{ Sugarcane bagasse levels (\%) } \\
\hline & & 30 & 38 & 46 & 54 \\
\hline & \multicolumn{5}{|c|}{ Feeding costs } \\
\hline Daily total diet offered (kg per cow) & 5.63 & 5.63 & 5.48 & 4.95 & 4.28 \\
\hline Diet cost $\left(\$ \mathrm{~kg}^{-1}\right)$ & 0.22 & 0.27 & 0.26 & 0.24 & 0.23 \\
\hline \multirow[t]{2}{*}{ Daily feeding cost (\$ per cow) } & 4.10 & 4.94 & 4.56 & 3.90 & 3.17 \\
\hline & \multicolumn{5}{|c|}{ Gross revenue } \\
\hline Daily milk yield (kg) & 6.12 & 6.98 & 6.58 & 5.97 & 5.08 \\
\hline Milk price $\left(\$ \mathrm{~kg}^{-1}\right)$ & 0.46 & 0.46 & 0.46 & 0.46 & 0.46 \\
\hline Daily gross revenue (\$ per cow) & 9.18 & 10.48 & 9.88 & 8.95 & 7.62 \\
\hline Gross margin $\left(\$\right.$ per cow day $\left.{ }^{-1}\right)$ & 5.09 & 5.53 & 5.31 & 5.06 & 4.44 \\
\hline Feeding cost per kg of milk produced (\$) & 0.21 & 0.22 & 0.21 & 0.20 & 0.19 \\
\hline
\end{tabular}

${ }^{(1)}$ Brazilian Reais quotation for U.S. dollar in July 2017: R\$ 3.25.

\section{Conclusion}

The inclusion of sugarcane bagasse as roughage for crossbred dairy cow's diet decreases their performance; nevertheless, the bagasse can be used as exclusive roughage, when associated with $70 \%$ of the concentrate, which is a sound alternative for dairy production in the Brazilian semiarid region due to the low availability of roughage in prolonged dry seasons.

\section{Acknowledgments}

To Conselho Nacional de Desenvolvimento Científico e Tecnológico (CNPq), for financial support (process number 477546/2012-9).

\section{References}

ADEWUYI, A.A.; GRUYS, E.; VAN EERDENBURG, F.J.C.M. Non esterified fatty acids (NEFA) in dairy cattle: a review. Veterinary Quarterly, v.27, p.117-126, 2005. DOI: 10.1080/01652176.2005.9695192.

AHMED, M.H.; BABIKER, S.A. Effect of feeding urea-treated sugar-cane bagasse on properties and quality of fresh meat of Sudan Baggara Zebu bulls. International Journal Animal Biology, v.1, p.45-49, 2015.

AHMED, M.H.; BABIKER, S.A.; FADEL ELSEED, A.E.M.A.; MOHAMMED, A.M. Effect of urea-treatment on nutritive value of sugarcane bagasse. ARPN Journal of Science and Technology, v.3, p.839-843, 2013.

BEN SALEM, H. Nutritional management to improve sheep and goat performances in semiarid regions. Revista Brasileira de Zootecnia, v.39, p.337-347, 2010. DOI: 10.1590/S151635982010001300037.
CARBON sequestration in dryland soils. Rome: Food and Agriculture Organization of the United Nations, 2004. 112p. (FAO. World soil resources reports, 102).

CHALUPA, W.; SNIFFEN, C.J. Balancing rations for milk components. Asian Australian Journal of Animal Science, v.13, p.388-396, 2000. Supplement.

CHEN, X.B.; GOMES, M.J. Estimation of microbial protein supply to sheep and cattle based on urinary excretion of purine derivatives: an overview of the technical details. Aberdeen: Rowett Research Institute, 1992. 21p.

CHIZZOTTI, M.L.; VALADARES FILHO, S. de C.; VALADARES, R.F.D.; CHIZZOTTI, F.H.M; TEDESCHI, L.O. Determination of creatinine excretion and evaluation of spot urine sampling in Holstein cattle. Livestock Science, v.113, p.218-225, 2008. DOI: 10.1016/j.livsci.2007.03.013.

FERREIRA, M. de A.; BISPO, S.V.; ROCHA FILHO, R.R.; URBANO, S.A.; COSTA, C.T.F. The use of cactus as forage for dairy cows in semi-arid regions of Brazil. In: KONVALINA, P. (Org.). Organic farming and food production. South Bohemia: InTech, 2012. p.169-189.

FERREIRA, M. de A.; PESSOA, R.A.S.; BISPO, S.V. Otimização de dietas a base de palma forrageira e outras alternativas de suplementação para regiões semi-áridas. In: SIMPÓSIO DE PRODUÇÃO DE GADO DE CORTE, 7.; SIMPÓSIO INTERNACIONAL DE PRODUÇÃO DE GADO DE CORTE, 3., 2010, Viçosa. Anais. Viçosa: Ed. da UFV, 2010. p.241-266.

GONZÁlEZ, F.D.; MUIÑO, R.; PEREIRA, V.; CAMPOS, R.; BENEDITO, J.L. Relationship among blood indicators of lipomobilization and hepatic function during early lactation in high-yielding dairy cows. Journal of Veterinary Science, v.12, p.251-255, 2011. DOI: $10.4142 /$ jvs.2011.12.3.251.

HALL, M.B. Recent advanced in non-NDF carbohydrates for the nutrition of lactating cows. In: SIMPÓSIO INTERNACIONAL EM BOVINOS DE LEITE, 2., 2001, Lavras. Novos conceitos em nutrição: anais. Lavras: Ed. da UFLA, 2001. p.139-148. 
HOFSETZ, K.; SILVA, M.A. Brazilian sugarcane bagasse: energy and non-energy consumption. Biomass Bioenergy, v.46, p.564573, 2012. DOI: 10.1016/j.biombioe.2012.06.038.

HORWITZ, W. Official methods of analysis of AOAC International. $17^{\text {th }}$ ed. Gaithersburg: AOAC International, 2000.

INÁCIO, J.G.; FERREIRA, M. de A.; SILVA, R.C.; SILVA, J. de L.; OLIVEIRA, J.C.V.; SANTOS, D.C. dos; SOARES, L.F.P.; CAMPOS, J.M. de S. Sugarcane bagasse as exclusive roughage for dairy heifers. Revista Brasileira de Zootecnia, v.46, p.80-84, 2017. DOI: 10.1590/s1806-92902017000100012.

ISO. International Organization for Standardization. ISO 9622:2013 (IDF 141:2013): milk and liquid milk products: guidelines for the application of mid-infrared spectrometry. Geneva: International Organization for Standardization, 2013. 14p.

KOOHAFKAN, P.; STEWART, B.A. Water and cereals in drylands. London: Food and Agriculture Organization of the United Nations: Earthscan, 2008. 113p.

KÖPPEN, W. Climatologia: con un estudio de los climas de la tierra. México: Fondo de Cultura Econômica, 1948. 479p.

LICITRA, G.; HERNANDEZ, T.M.; VAN SOEST, P.J. Standardization of procedures for nitrogen fractionation of ruminant feeds. Animal Feed Science and Technology, v.57, p.347-358, 1996. DOI: 10.1016/0377-8401(95)00837-3.

LOBELL, D.B.; GOURDJI, S.M. The influence of climate change on global crop productivity. Plant Physiology, v.160, p.1686-1697, 2012. DOI: $10.1104 / p p .112 .208298$.

MARTIN, P.; BATESON, P. Measuring behavior: an introductory guide. $3^{\text {rd }}$ ed. Cambridge: Cambridge University Press, 2007. 176p. DOI: 10.1017/CBO9780511810893.

MERTENS, D.R. Creating a system for meeting the fiber requirements of dairy cows. Journal of Dairy Science, v.8, p.1463-1481, 1997. DOI: 10.3168/jds.S0022-0302(97)76075-2.

MERTENS, D.R. Gravimetric determination of amylase-treated neutral detergent fiber in feeds with refluxing in beakers or crucibles: collaborative study. Journal of AOAC International, v.85, p.1217-1240, 2002.

MORTIMORE, M.; ANDERSON, S.; COTULA, L.; DAVIES, J.; FACCER, K.; HESSE, C.; MORTON, J.; NYANGENA, W.; SKINNER, J.; WOLFANGEL, C. Dryland opportunities: a new paradigm for people, ecosystems and development. Gland: International Union for Conservation of Nature, 2009. 86p.

NRC. National Research Council. Nutrient requirements of dairy cattle. $7^{\text {th }}$ rev. ed. Washington: National Academy Press, 2001. 381p. DOI: $10.17226 / 9825$.

PARENTE, H.N.; PARENTE, M. de O.M.; GOMES, R.M. da S.; SODRÉ, W. de J. dos S.; MOREIRA FILHO, M.A.; RODRIGUES, R.C.; SANTOS, V.L.F. dos; ARAÚJO, J. dos S. Increasing levels of concentrate digestibility, performance and ingestive behavior in lambs. Revista Brasileira de Saúde e Produção Animal, v.17, p.186-194, 2016. DOI: 10.1590/S1519-99402016000200006.

PINA, D. dos S.; VALADARES, R.F.D.; VALADARES FILHO, S. de C.; CHIZZOTTI, M.L. Degradação ruminal da proteína dos alimentos e síntese de proteína microbiana. In: VALADARES FILHO, S. de C.; MARCONDES, M.I.; CHIZZOTTI, M.L.; PAULINO, P.V.R. (Ed.). Exigências nutricionais de zebuínos puros e cruzados: BR - Corte. Viçosa: Ed. da UFV, 2010. p.13-46. SIQUEIRA, M.C.B.; FERREIRA, M. de A.; MONNERAT, J.P.I. dos S.; SILVA, J. de L.; COSTA, C.T.F.; CONCEICÃO, M.G. da; ANDRADE, R. de P.X. de; BARROS, L.J.A.; MELO, T.T. de B. Optimizing the use of spineless cactus in the diets of cattle: total and partial digestibility, fiber dynamics and ruminal parameters. Animal Feed Science and Technology, v.226, p.56-64, 2017. DOI: $10.1016 /$ j.anifeedsci.2016.12.006.

SKLAN, D.; ASHKENAZI, R.; BRAUN, A.; DEVORIN, A.; TABORI, K. Fatty acids, calcium soaps of fatty acids, and cottonseeds fed to high yielding cows. Journal of Dairy Science, v.75, p.2463-2472, 1992. DOI: 10.3168/jds.S0022-0302(92)78008-4.

TITGEMEYER, E.C. Amino acid utilization by growing and finishing ruminants. In: D'MELLO, J.P.F. (Ed.). Amino acids in animal nutrition. $2^{\text {nd }}$ ed. Wallingford: CAB International, 2003. p.329-346. DOI: 10.1079/9780851996547.0329.

VALENTE, T.N.P.; DETMANN, E.; SAMPAIO, C.B. Review: recent advances in evaluation of bags made from different textiles used in situ ruminal degradation. Canadian Journal of Animal Science, v.95, p.493-498, 2015. DOI: 10.4141/cjas-2015-100.

WEISS, W.P. Energy prediction equations for ruminant feeds. In: PROCEEDINGS OF THE CORNELL NUTRITION CONFERENCE FOR FEED MANUFACTURES, 61., 1999, Ithaca. Proceedings. Ithaca: Cornell University, 1999. p.176-185.

Received on March 22, 2017 and accepted on July 11, 2017 